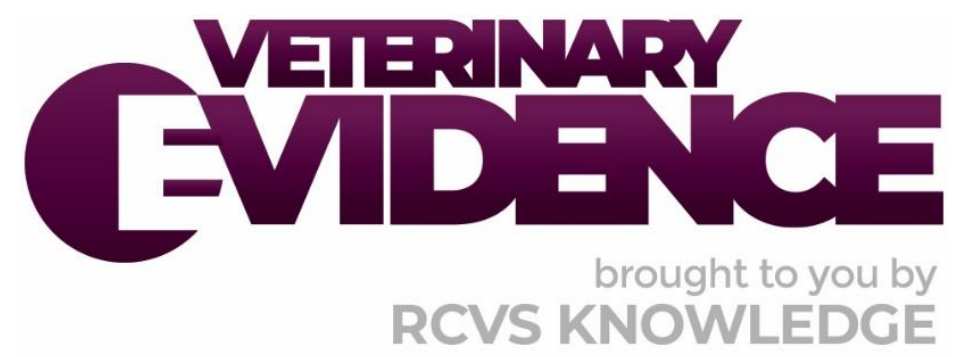

\title{
Is a cross-match necessary before a cat's first blood transfusion?
}

A Knowledge Summary by

Ben Safrany BVetMed, $\operatorname{PgC}(\mathrm{SAM}), \mathrm{MRCVS}^{1^{*}}$

Sophie Adamantos BVSc, CertVA, DACVECC, DipECVECC, MRCVS, FHEA ${ }^{1}$

\footnotetext{
${ }^{1}$ Paragon Veterinary Referrals, Paragon Business Village, Paragon Way, Red Hall Crescent, Wakefield, WF1 2DF

*Corresponding Author (Ben.Safrany@paragonreferrals.co.uk)
}

ISSN: 2396-9776

Published: 06 May 2020

in: Vol 5, Issue 2

DOI: 10.18849/VE.V5I2.306

Reviewed by: Nicolette Joosting (BSc, BVSc) and Conor O'Halloran (BVSc, MRCVS)

Next Review Date: 11 Nov 2021

$\left.\begin{array}{l}\text { OPEN } \\ \text { ACCESS }\end{array} \quad \begin{array}{l}\text { PEER } \\ \text { REVIEWED }\end{array}\right\}$




\section{KNOWLEDGE SUMMARY}

\section{PICO question}

In transfusion-naïve cats receiving a type specific blood transfusion is cross-matched blood (major and minor) associated with an increased haematocrit development and reduction in acute transfusion reactions when compared with those receiving non-crossmatched blood?

\section{Clinical bottom line}

\section{Category of research question}

Treatment

\section{The number and type of study designs reviewed}

Ten papers were critically reviewed. There were four retrospective case series, three prospective crosssectional surveys, a retrospective cohort study, a prospective case series and a prospective randomised control trial.

\section{Strength of evidence \\ Weak}

\section{Outcomes reported}

It would appear that in the United Kingdom the incidence of non-AB transfusion reactions is low. A single study suggests that cross-matching may result in a greater improvement in haematocrit, but this is unlikely to be clinically significant. There is evidence to support the hypothesis that non-AB antigens (for example the Mik antigen) differ with geographic distribution.

\section{Conclusion}

Based on the information available it is it is challenging to establish a meaningful clinical conclusion on which to base a recommendation.

\section{How to apply this evidence in practice}

The application of evidence into practice should take into account multiple factors, not limited to: individual clinical expertise, patient's circumstances and owners' values, country, location or clinic where you work, the individual case in front of you, the availability of therapies and resources.

Knowledge Summaries are a resource to help reinforce or inform decision making. They do not override the responsibility or judgement of the practitioner to do what is best for the animal in their care.

\section{Clinical Scenario}

You are presented with a 5-year-old, neutered male domestic shorthair cat with a 3 day history of progressive lethargy and hyporexia. A complete blood count reveals a severe, regenerative anaemia (Packed cell volume (PCV) 11\%). Serum biochemistry identifies mild hyperbilirubinaemia. You are suspicious of immune mediated haemolytic anaemia and send blood to a reference laboratory for further analysis. Survey imaging of the thorax and abdomen is normal. The cat is blood type $A$.

You feel a blood transfusion is needed/required. The cat's owners have another cat who is a suitable blood donor and is also type A. You wonder whether to proceed with transfusion of blood from this cat immediately, or whether to perform a cross-match first. 


\section{The evidence}

The evidence available consists of predominantly retrospective descriptive studies, with some prospective experimental studies. The retrospective studies have inherent bias and are therefore low on the hierarchy of evidence. Furthermore, type independent cross-match incompatibilities are not the primary outcome studied in most papers. This has led to inconsistency in areas of study design including methodology of blood typing and cross-matching, criteria for transfusion, blood product used (packed red blood cells versus whole blood), data collected and methods for calculating scaled haematocrit development (if used). As a result, it is challenging to establish a meaningful clinical conclusion.

Hct - Haematocrit

PCV - Packed cell volume

pRBC - Packed red blood cells

Summary of the evidence

\begin{tabular}{|c|c|}
\hline \multicolumn{2}{|l|}{ Binagia et al. (2016) } \\
\hline \multicolumn{2}{|l|}{$\begin{array}{l}\text { Binagia et al. (2016) } \\
\text { Population: }\end{array}$} \\
\hline \multirow{2}{*}{$\begin{array}{r}\text { Sample size: } \\
\text { Intervention details: }\end{array}$} & 126 cats receiving 102 transfusions \\
\hline & $\begin{array}{l}\text { - Medical records were reviewed to select cats blood type in } \\
\text { anticipation of a blood transfusion. } \\
\text { Cats receiving a cross-match were compared with those that } \\
\text { did not. }\end{array}$ \\
\hline Study design: & Retrospective dual-centre cohort study \\
\hline Outcome studied: & $\begin{array}{l}\text { - Incidence of transfusion reactions. } \\
\text { - } \quad \text { Post transfusion PCV, survival, time to discharge. }\end{array}$ \\
\hline $\begin{array}{l}\text { Main findings: } \\
\text { (relevant to PICO question): }\end{array}$ & $\begin{array}{l}\text { - There was no difference in the rate of transfusion reactions, } \\
\text { post-transfusion PCV, or survival between groups. } \\
\text { - The non-crossmatched group had a significantly longer } \\
\text { duration of hospitalisation. }\end{array}$ \\
\hline Limitations: & $\begin{array}{l}\text { - This was a retrospective study and is therefore subject to } \\
\text { more bias than an equivalent prospective study. Accuracy } \\
\text { relies on accurate record keeping, it is possible transfusion } \\
\text { reactions could be under-reported, timings of pre and post- } \\
\text { transfusion PCV may be inconsistent. } \\
\text { - Only the abstract is available, so key information (for example } \\
\text { the incidence of transfusion reactions) is not available for } \\
\text { review. } \\
\text { - It is not stated whether cases were transfusion naïve. Given } \\
\text { the retrospective nature it is likely that the cats that received } \\
\text { cross-matches were previously transfused. } \\
\text { The method and type (major or minor) of cross-match is not } \\
\text { stated. } \\
\text { The criteria for reporting a transfusion reaction are not } \\
\text { defined. }\end{array}$ \\
\hline
\end{tabular}




\begin{tabular}{|c|c|}
\hline \multicolumn{2}{|l|}{ Goy-Thollot et al. (2019) } \\
\hline Population: & $\begin{array}{l}\text { Healthy, transfusion naïve domestic shorthair cats over the age of } 1 \\
\text { year presenting at a hospital in Lyon, France between October } 2017 \\
\text { and March } 2017 .\end{array}$ \\
\hline Sample size: & 49 cats \\
\hline Intervention details: & $\begin{array}{l}\text { Blood samples collected from healthy cats presenting for } \\
\text { wellness examination or neutering. } \\
\text { Blood typing was performed using immunochromatographic } \\
\text { and flow cytometric techniques. } \\
\text { Major cross-matching was performed using gel column (GC) } \\
\text { (major cross-match only) and feline antiglobulin-enhanced gel } \\
\text { column (AGC). }\end{array}$ \\
\hline Study design: & Single centre prospective cross-sectional survey \\
\hline Outcome studied: & $\begin{array}{l}\text { - The presence of naturally occurring alloantibodies in cats. } \\
\text { - The sensitivity of the AGC compared with the GC method of } \\
\text { cross-matching. } \\
\text { - The agreement between immunochromatographic and flow } \\
\text { cytometric techniques of blood typing. }\end{array}$ \\
\hline $\begin{array}{l}\text { Main findings: } \\
\text { (relevant to PICO question): }\end{array}$ & $\begin{array}{l}\text { - Incompatibilities outside of the major AB system were } \\
\text { detected in } 3 / 49 \text { cats and were only detected using the AGC } \\
\text { test. } \\
\text { - There was a good agreement between the two cross-match } \\
\text { methods, with additional incompatibilities detected by the } \\
\text { AGC method. }\end{array}$ \\
\hline Limitations: & $\begin{array}{l}\text { - There is only a small sample size. } \\
\text { - The study population is healthy and therefore different to } \\
\text { clinically affected cats requiring transfusion. } \\
\text { There is no gold standard cross-matching test to compare the } \\
\text { results to, so it is not clear if additional incompatibilities were } \\
\text { revealed but the AGC method gives false positives, or if the GC } \\
\text { technique underestimated the incidence of incompatible } \\
\text { cross-matches. } \\
\text { The AGC technique has not been used in any of the other } \\
\text { studies, making comparison difficult. }\end{array}$ \\
\hline
\end{tabular}

\begin{tabular}{|r|l|}
\hline \multicolumn{2}{|l|}{ Hourani et al. (2017) } \\
\hline Population: & $\begin{array}{l}\text { Hospitalised anaemic cats receiving a type specific whole blood } \\
\text { transfusion at the University of Berlin (dates not provided). }\end{array}$ \\
\hline Sample size: & 21 cats received 33 blood transfusions \\
\hline Intervention details: & $\begin{array}{l}\text { - } \begin{array}{l}\text { Medical records were reviewed to select cats receiving a } \\
\text { transfusion of type specific whole blood. } \\
\end{array} \\
\text { - Major, minor and recipient control cross-matches were } \\
\text { performed before all transfusions and then every } 2 \text { days } \\
\text { thereafter. }\end{array}$ \\
\hline
\end{tabular}




\begin{tabular}{|c|c|}
\hline & $\begin{array}{l}\text { - Cross-matching was performed in-house using standard and } \\
\text { tube protocol. }\end{array}$ \\
\hline Study design: & Prospective single centre case series \\
\hline Outcome studied: & $\begin{array}{l}\text { - Major, minor and control cross-match status. } \\
\text { - Hct development. }\end{array}$ \\
\hline $\begin{array}{l}\text { Main findings: } \\
\text { (relevant to PICO question): }\end{array}$ & $\begin{array}{l}\text { - No acute transfusion reactions were recorded. } \\
\text { - } 15 / 21 \text { cats' major cross-matches remained compatible } \\
\text { throughout. } \\
\text { - } 5 / 20 \text { [sic] cats developed major cross-match incompatibility } \\
\text { - } \quad \text { No incompatible cross-matches in transfusion naïve patients. } \\
\text { - } \quad \text { Hct development as expected in } 17 / 33 \text { transfusions. } \\
\text { - Cross-match incompatible patients achieved a Hct on average } \\
\text { - } 1.04 \% \text { less than expected. } \\
\text { Cross-match compatible patients achieved a Hct on average } \\
0.53 \% \text { more than expected. }\end{array}$ \\
\hline Limitations: & $\begin{array}{l}\text { - Cross-matches performed on stored samples, older samples } \\
\text { may increase the occurrence of incompatible cross-matches. } \\
\text { - } \quad \text { In-house cross-matching only. } \\
\text { Bilirubin not measured, may have aided the detection of } \\
\text { delayed transfusion reactions. } \\
\text { - Small sample size. }\end{array}$ \\
\hline
\end{tabular}

\begin{tabular}{|c|c|}
\hline \multicolumn{2}{|l|}{ Klaser et al. (2005) } \\
\hline Population: & $\begin{array}{l}\text { Cats receiving transfusion of type specific whole blood or pRBCs at } \\
\text { the Animal Medical Centre, New York between January and } \\
\text { December } 1999 .\end{array}$ \\
\hline Sample size: & 126 cats receiving 148 transfusions \\
\hline Intervention details: & $\begin{array}{l}\text { - Medical records were reviewed to identify cats receiving a } \\
\text { blood transfusion. } \\
\text { - A cross-match was only performed in the event of a previous } \\
\text { transfusion over } 4 \text { days earlier. }\end{array}$ \\
\hline Study design: & Retrospective single centre case series \\
\hline Outcome studied: & $\begin{array}{l}\text { - Number of and reasons for transfusions. } \\
\text { - Incidence of acute transfusion reactions. } \\
\text { - Volume of blood administered, change in PCV and clinical } \\
\text { outcome. }\end{array}$ \\
\hline $\begin{array}{l}\text { Main findings: } \\
\text { (relevant to PICO question): }\end{array}$ & $\begin{array}{l}\text { - } 127 / 148 \text { whole blood transfusions, } 21 / 148 \text { pRBC transfusions. } \\
\text { - A median increase in PCV of } 6.4 \pm 3.9 \% \text { was observed in all } \\
\text { cats. } \\
\text { Acute transfusion reactions occurred in } 11 / 148(7.4 \%) \\
\text { transfusions, of these, } 10 \text { were acute non-haemolytic } \\
\text { transfusion reactions and one was an acute haemolytic } \\
\text { reaction in a untyped cat, suspected to have been transfused } \\
\text { with blood of an incompatible type. }\end{array}$ \\
\hline
\end{tabular}




\begin{tabular}{|l|ll|}
\hline Limitations: & $\begin{array}{l}\text { - Retrospective study design. } \\
\text { - }\end{array}$ \\
& $\begin{array}{l}\text { The increase in Hct, incidence of incompatible cross-matches } \\
\text { and method of cross-matching were not reported. }\end{array}$ \\
\hline
\end{tabular}

\begin{tabular}{|c|c|}
\hline \multicolumn{2}{|l|}{ McClosky et al. (2018) } \\
\hline Population: & $\begin{array}{l}\text { Cats receiving a type specific RBC transfusion at the University of } \\
\text { Pennsylvania between January, } 2013 \text { and December, } 2016 \text {. }\end{array}$ \\
\hline Sample size: & 300 cats ( 220 transfusion naïve) \\
\hline Intervention details: & $\begin{array}{l}\text { - Medical records were reviewed to identify cats receiving a } \\
\text { transfusion with or without a major cross-match. } \\
\text { - Cross-matches were performed using the tube method. }\end{array}$ \\
\hline Study design: & Retrospective single centre case series \\
\hline Outcome studied: & $\begin{array}{l}\text { - Incidence of major cross-match incompatibilities. } \\
\text { - Scaled increase in PCV. } \\
\text { - Incidence of transfusion reaction. } \\
\text { - Survival to discharge, } 30 \text { and } 60 \text { day survival. }\end{array}$ \\
\hline $\begin{array}{l}\text { Main findings: } \\
\text { (relevant to PICO question): }\end{array}$ & $\begin{array}{l}\text { - Major cross-match incompatibilities in 23/154 (14.9\%) } \\
\text { transfusion naïve cats and } 15 / 55 \text { (27\%) previously transfused } \\
\text { cats. } \\
\text { - Cross-matched blood was not associated with significant } \\
\text { difference in scaled increase in PCV when compared with non- } \\
\text { crossmatched blood ( }+0.76 \mathrm{ml} / \mathrm{kg} \text { and }+0.97 \mathrm{ml} / \mathrm{kg} \\
\text { respectively). } \\
\text { - Febrile transfusion reactions occurred in } 8 / 79(10.1 \%) \text { of non- } \\
\text { crossmatched transfusions and } 4 / 161(2.5 \%) \text { cross-matched } \\
\text { transfusions. } \\
\text { - Six cats were administered cross-match incompatible units } \\
\text { (one transfusion naïve), no reactions were observed and the } \\
\text { scaled increase in PCV was +0.86 ml/kg. } \\
\text { Cross-match not associated with improved survival to } \\
\text { discharge or } 30 \text { and } 60 \text { day survival. } \\
\text { Two non-crossmatched cats developed suspected transfusion } \\
\text { associated adverse effects and died. Post-mortem } \\
\text { compatibility testing or necropsy were not performed. }\end{array}$ \\
\hline Limitations: & $\begin{array}{l}\text { - This was a retrospective study and is therefore subject to } \\
\text { more bias than an equivalent prospective study. Accuracy } \\
\text { relies on accurate record keeping, it is possible transfusion } \\
\text { reactions could be under-reported, timings of pre and post- } \\
\text { transfusion PCV may be inconsistent. } \\
\text { - Although a reduction of transfusion reactions was observed in } \\
\text { cats receiving a cross-match it is not clear if this applies to } \\
\text { transfusion naïve cats. } \\
\text { - Some (8\%) cross-matches performed by case clinician rather } \\
\text { than laboratory staff. } \\
\text { A febrile transfusion reaction was defined as an increase in } \\
\text { body temperature } \geq 2^{\circ} \mathrm{F} \text { during or within } 4 \text { hours of the }\end{array}$ \\
\hline
\end{tabular}




\begin{tabular}{|c|c|}
\hline & $\begin{array}{l}\text { transfusion. It is possible that this criteria will overestimate } \\
\text { the rate of febrile transfusion reactions. } \\
\text { The two cats that died were not included in adverse event } \\
\text { statistics, it is unclear if their deaths were transfusion related } \\
\text { or related to an underlying disease. }\end{array}$ \\
\hline
\end{tabular}

\begin{tabular}{|c|c|}
\hline \multicolumn{2}{|l|}{ Sylvane et al. (2018) } \\
\hline Population: & $\begin{array}{l}\text { Transfusion naïve cats, older than } 4 \text { months, receiving type specific } \\
\text { pRBC transfusion at the Animal Medical Centre, New York from } \\
\text { January } 2016 \text { to August } 2017 .\end{array}$ \\
\hline Sample size: & 48 cats \\
\hline Intervention details: & $\begin{array}{l}\text { - Each cat was randomised to have a major cross-match or not } \\
\text { before transfusion ( } 24 \text { cats in each group). } \\
\text { - } 24 / 48 \text { cross-matched cats received type specific cross- } \\
\text { matched blood. } \\
\text { - } 24 / 48 \text { non-crossmatched cats received type specific non- } \\
\text { cross-matched blood. } \\
\text { - Blood transfusion was initiated } 2 \text { hours after the initial PCV } \\
\text { - } \text { measurement in both groups. } \\
\text { - donen cross-matched, each cat was matched to at least } 2 \\
\text { - All cross-matches were performed at an external reference } \\
\text { laboratory. } \\
\text { Donor blood was sourced from a commercial blood bank. }\end{array}$ \\
\hline Study design: & Prospective randomised control trial \\
\hline Outcome studied: & $\begin{array}{l}\text { - Incidence of acute transfusion reactions. } \\
\text { - Scaled increase in PCV. }\end{array}$ \\
\hline $\begin{array}{l}\text { Main findings: } \\
\text { (relevant to PICO question): }\end{array}$ & $\begin{array}{l}\text { - Cross-matched cats were cross-matched to at least } 2 \text { units of } \\
\text { - } \quad 10 / 52 \text { (19\%) incompatible cross-matches. } \\
\text { - } 4 / 24 \text { transfusion reactions ( } 16.7 \%) \text { in cross-matched group, } \\
\text { three were febrile non-haemolytic transfusion reactions } \\
\text { (FNHTR), one was a suspected haemolytic transfusion } \\
\text { reaction. } \\
\text { - } 7 / 24 \text { transfusion reactions ( } 29.1 \%) \text { in non-crossmatched } \\
\text { group, all were FNHTR. } \\
\text { There was no significant difference in the rate of transfusion } \\
\text { reactions between groups. } \\
\text { No significant difference in mean PCV post-transfusion scaled } \\
\text { to the dose of pRBC administered was detected between } \\
\text { groups. }\end{array}$ \\
\hline Limitations: & $\begin{array}{l}\text { - This study has a relatively small sample size. } \\
\text { - The Hct of transfused units of pRBC were not recorded. } \\
\text { - FNHTR defined as an increase in body temperature by } 1^{\circ} \mathrm{C} \\
\text { during the transfusion without evidence of haemolysis. There } \\
\text { is a risk of this criteria over-reporting transfusion reactions. }\end{array}$ \\
\hline
\end{tabular}




\begin{tabular}{|c|c|}
\hline Population: & $\begin{array}{l}\text { Transfusion naïve cats presenting to the University of Bristol, UK for } \\
\text { clinical evaluation for ill health or as potential blood donors between } \\
\text { January and October } 2012 \text {. }\end{array}$ \\
\hline Sample size: & 112 cats \\
\hline Intervention details: & 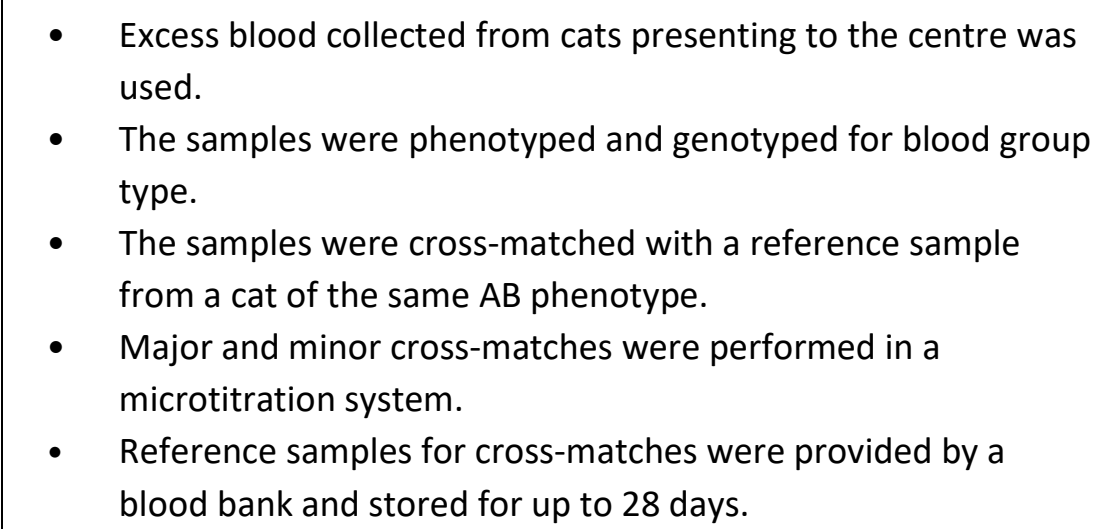 \\
\hline Study design: & Single centre cross-sectional survey \\
\hline Outcome studied: & $\begin{array}{l}\text { - The agreement between AB blood phenotyping and } \\
\text { genotyping. } \\
\text { - The incidence of incompatible cross-matches in type specific } \\
\text { blood. }\end{array}$ \\
\hline $\begin{array}{l}\text { Main findings: } \\
\text { (relevant to PICO question): }\end{array}$ & $\begin{array}{l}\text { - No major cross-match incompatibility was detected. } \\
\text { - } \quad \text { No incompatible minor cross-matches. } \\
\text { incompatibilities. }\end{array}$ \\
\hline Limitations: & $\begin{array}{l}\text { - Cross-matches performed with limited number of reference } \\
\text { samples. } \\
\text { - Reference samples were obtained from USA. } \\
\text { mis study only reports the incidence of incompatible cross- } \\
\text { matches performed on type specific blood, not the outcome } \\
\text { of transfusion. }\end{array}$ \\
\hline
\end{tabular}

\begin{tabular}{|c|c|}
\hline \multicolumn{2}{|l|}{ Weingart et al. (2004) } \\
\hline Population: & $\begin{array}{l}\text { Cats receiving a type specific RBC transfusion at the University of } \\
\text { Berlin between September } 1998 \text { and August } 2001 .\end{array}$ \\
\hline Sample size: & 91 cats receiving 163 transfusions \\
\hline Intervention details: & $\begin{array}{l}\text { - Medical records were reviewed to identify cats receiving a } \\
\text { transfusion of type specific fresh whole blood. } \\
\text { Major and minor cross-matches were performed using the } \\
\text { tube method. }\end{array}$ \\
\hline Study design: & Retrospective single centre case series \\
\hline Outcome studied: & $\begin{array}{l}\text { - Indications for transfusion. } \\
\text { - } \quad \text { Hct development. }\end{array}$ \\
\hline
\end{tabular}




\begin{tabular}{|c|c|}
\hline & $\begin{array}{l}\text { - } \quad \text { Transfusion frequency and volume. } \\
\text { - } \quad \text { Survival rate. } \\
\text { - } \quad \text { Plansfusion reactions. } \\
\text { transfusions). }\end{array}$ \\
\hline $\begin{array}{l}\text { Main findings: } \\
\text { (relevant to PICO question): }\end{array}$ & $\begin{array}{l}\text { - Transfusion performed for a variety of reasons including blood } \\
\text { loss, haemolysis, ineffective erythropoiesis, hypoproteinaemia } \\
\text { and severe coagulopathy. } \\
\text { - A mild increase in serum bilirubin was detected in 11/29 (38\%) } \\
\text { cases. } \\
\text { Transfusion reactions were noted in } 2 / 163(1.2 \%) \\
\text { transfusions. Both were compatible in type and cross-match } \\
\text { and were receiving their second and third transfusions. } \\
\text { There were } 7 / 60 \text { (11.7\%) incompatible major cross-matches, } \\
\text { one was in a transfusion naïve cat. Transfusions were } \\
\text { administered regardless, no clinical transfusion reactions were } \\
\text { observed, Hct development was as expected in five cases, but } \\
\text { remained unchanged in two. }\end{array}$ \\
\hline Limitations: & $\begin{array}{l}\text { - This was a retrospective study and is therefore subject to } \\
\text { more bias than an equivalent prospective study. Accuracy } \\
\text { relies on accurate record keeping, it is possible transfusion } \\
\text { reactions could be under-reported, timings of pre and post- } \\
\text { transfusion PCV may be inconsistent. } \\
\text { - The number of transfusion naïve cats was not reported. } \\
\text { - Cross-matches were not performed in all cats prior to } \\
\text { transfusion. It is not clear how many transfusion naïve cats } \\
\text { were tested prior to transfusion. } \\
\text { Nearly half (44\%) of cats included in the study had multiple } \\
\text { transfusions, potentially increasing the risk of transfusion } \\
\text { reactions. } \\
\text { Much lower reported incidence of transfusion reactions } \\
\text { compared with other studies, it is possible transfusion } \\
\text { reactions were under recognised and reported. }\end{array}$ \\
\hline
\end{tabular}

Weinstein et al. (2007)

\begin{tabular}{|r|l|}
\hline Population: & $\begin{array}{l}\text { Type A blood donor cats and a renal transplant recipient presenting } \\
\text { at the University of Pennsylvania (dates not stated). }\end{array}$ \\
\hline Sample size: & 66 cats \\
\hline Intervention details: & $\begin{array}{r}\text { - All cats blood-typed them major and minor cross-matches } \\
\text { were performed. }\end{array}$ \\
& $\begin{array}{l}\text { Cross-matches performed using the tube and gel column } \\
\text { methods. }\end{array}$ \\
& $\begin{array}{l}\text { Agglutinin titres then performed to characterise } \\
\text { alloantibodies. }\end{array}$ \\
\hline Study design: & Prospective single centre cross-sectional survey and case report \\
\hline
\end{tabular}




\begin{tabular}{|c|ll|}
\hline Outcome studied: & - & Incidence of incompatible cross-matches in type A blood. \\
\hline (relevant to PICO question): & Presence of auto and alloantibodies.
\end{tabular}

\begin{tabular}{|c|c|}
\hline \multicolumn{2}{|l|}{ Weltman et al. (2014) } \\
\hline Population: & $\begin{array}{l}\text { Cats receiving a type specific transfusion of pRBCs between } 2000 \\
\text { and } 2010 \text { at the Cornell University teaching hospital. }\end{array}$ \\
\hline Sample size: & 209 cats receiving 233 transfusions \\
\hline Intervention details: & $\begin{array}{l}\text { - PRBCs were administered with a major cross-match (43 } \\
\text { transfusions in } 36 \text { cats) or without a major cross-match (190 } \\
\text { transfusions in } 173 \text { cats). } \\
\text { - Cross-matches performed in all patients that received a } \\
\text { transfusion greater than } 3 \text { days previously or as requested by } \\
\text { the clinician in transfusion naïve cats. } \\
\text { - Cross-matches were performed using the tube method. }\end{array}$ \\
\hline Study design: & Single centre retrospective case series \\
\hline Outcome studied: & $\begin{array}{l}\text { The change in PCV following packed red blood cell administration } \\
\text { relative to dose of pRBCs administered. }\end{array}$ \\
\hline $\begin{array}{l}\text { Main findings: } \\
\text { (relevant to PICO question): }\end{array}$ & $\begin{array}{l}\text { The administration of type specific, cross-match compatible pRBCs } \\
\text { resulted in a significantly greater increase in PCV when compared to } \\
\text { non-crossmatched packed red blood cell administration. }\end{array}$ \\
\hline Limitations: & $\begin{array}{l}\text { - This was a retrospective study and is therefore subject to } \\
\text { more bias than an equivalent prospective study. Accuracy } \\
\text { relies on accurate record keeping, it is possible transfusion } \\
\text { reactions could be under-reported, timings of pre and post- } \\
\text { transfusion PCV may be inconsistent. }\end{array}$ \\
\hline
\end{tabular}




\begin{tabular}{|l|l|}
\hline - Non-crossmatched cats had a lower pretransfusion PCV, it is \\
possible that they represent a cohort of cats too unwell to \\
wait for a cross-match. \\
- Most cross-matched cats were not transfusion naïv, reducing \\
the relevance to the PICO question. \\
There is a difference in the aetiology of the anaemia between \\
study groups.
\end{tabular}

\section{Appraisal, application and reflection}

Traditionally, it has been advised that a cross-match has only been required prior to administering type specific blood to cats if they had a previous transfusion more than 4 days previously. Recently cross-match incompatibilities and transfusion reactions independent of the $A B$ system have been reported. It has been hypothesised that naturally occurring alloantibodies to alternative red blood cell antigens are responsible, with particular interest paid to the Mik antigen, first reported by Weinstein in 2007.

Weltman et al. (2014) showed that administering cross-match compatible blood lead to greater haematocrit development when compared with non-crossmatched transfusions. Binangia et al. (2016), Hourani et al. (2017) and Sylvane et al. (2018) failed to repeat these findings in more recent studies, but did identify a reduced frequency of pyrexic (non-haemolytic) transfusion reactions in cross-matched cats. However, Weingart et al. (2007) reports two cases with an incompatible cross-match where transfusion did not increase $\mathrm{PCV}$, suggesting treatment failure.

It is noteworthy that all reports of non- $A B$ transfusion reactions in transfusion naive cats originate in the United States, raising the possibility that a geographical element exists. In 2014, Tasker et al. were unable to demonstrate cross-match incompatibilities independent of the $A B$ system in a cohort of cats from the United Kingdom.

A limitation of the papers reviewed were inconsistencies relating to the method of cross-match and whether only a major cross-match, or major and minor cross-matches were performed. In a major cross-match the donor's erythrocytes are screened for incompatibility with the recipient's plasma, whereas a minor crossmatch tests for incompatibilities between donor plasma and recipient erythrocytes. Goy-Thollot et al. (2019) report an increased sensitivity of a feline antiglobulin-enhanced gel column method of cross-matching which was not used in any of the other studies. It is possible that such a technique is more sensitive that other techniques, however, the clinical significance of this is yet to be investigated.

The application of these studies to clinical cases is still debatable. The only prospective randomised study (Sylvane et al., 2018) failed to show a difference in transfusion reactions between cross-matched and noncrossmatched cats and no difference in increase in haematocrit following transfusion. Based upon the studies presented here it is challenging to establish a meaningful clinical conclusion on which to base a recommendation. 


\section{Methodology Section}

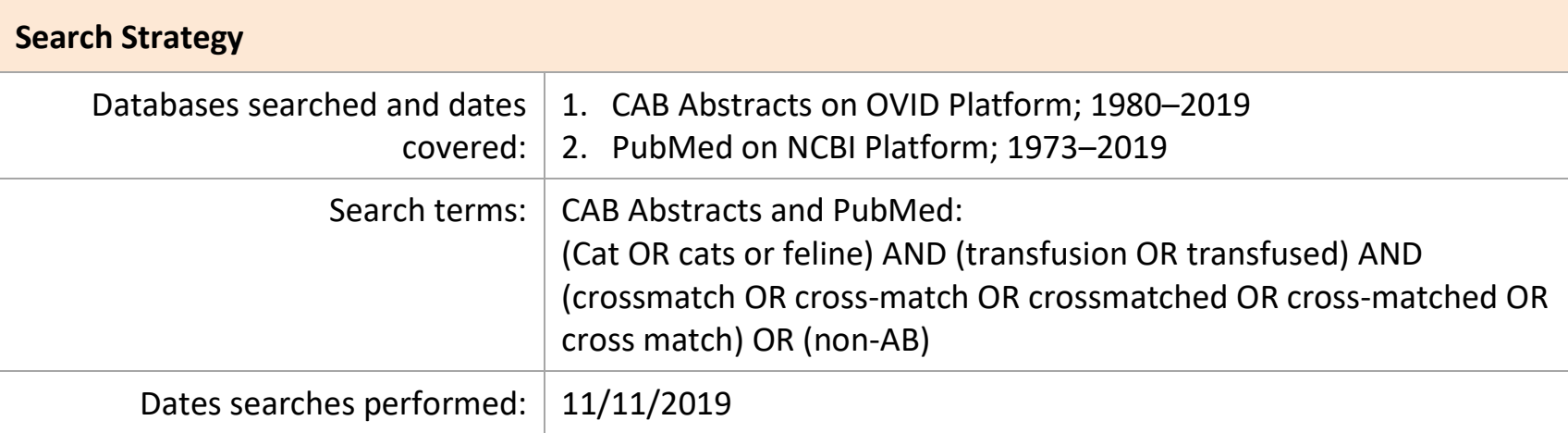

\section{Exclusion / Inclusion Criteria}

Exclusion: Book chapters, articles not available in English, clinical review articles.

Inclusion: Articles available in English which were relevant to the PICO. Articles had to involve more than one cat.

\begin{tabular}{|l|c|c|c|c|c|c|}
\hline \multicolumn{5}{|c|}{ Search Outcome } \\
\hline Database & $\begin{array}{c}\text { Number } \\
\text { of } \\
\text { results }\end{array}$ & $\begin{array}{c}\text { Excluded }- \\
\text { book } \\
\text { chapter }\end{array}$ & $\begin{array}{c}\text { Excluded - } \\
\text { clinical review } \\
\text { article }\end{array}$ & $\begin{array}{c}\text { Excluded - not } \\
\text { relevant to PICO }\end{array}$ & $\begin{array}{c}\text { Excluded - full } \\
\text { article not } \\
\text { available }\end{array}$ & $\begin{array}{c}\text { Total } \\
\text { relevant } \\
\text { papers }\end{array}$ \\
\hline CAB Abs & 39 & 1 & 1 & 29 & 0 & 8 \\
\hline PubMed & 117 & 0 & 9 & 96 & 2 & 10 \\
\hline Total relevant papers when duplicates removed & & & & 10 \\
\hline
\end{tabular}

\section{CONFLICT OF INTEREST}

The authors declare no conflict of interest. 


\section{REFERENCES}

1. Binagia, E., Mattison, B. \& Koenigshof, A. (2016). 'Cross-matched vs non-crossmatched feline blood transfusions and effects on transfusion reaction rates, post-transfusion packed cell volume, duration of hospitalisation, and survival', Journal of Veterinary Emergency Medicine and Critical Care, Abstract presented September 7-11, 2016 in Grapevine, TX, USA. DOI: http://dx.doi.org/10.1111/vec.12516

2. Goy-Thollot, I., Nectoux, A., Guidetti, M., Chaprier, B., Bourgeois, S., Boisvineau, C., Barthélemy, A., Pouzot-Nevoret, C. \& Giger, U. (2019). 'Detection of naturally occurring alloantibody by an in-clinic antiglobulin-enhanced and standard crossmatch gel column test in non-transfused domestic shorthair cats', Journal of Veterinary Internal Medicine, 33(2), pp. 588-595.

DOI: http://dx.doi.org/1111/jvim.15381

3. Hourani, L., Weingart, C. \& Kohn, B. (2017). 'Alloimmunisation in transfused patients: serial crossmatching in a population of hospitalised cats', Journal of Feline Medicine and Surgery, 19(12), pp. 12311237. DOI: http://dx.doi.org/10.1177/1098612X16688574

4. Klaser, D. A., Reine, N. J. \& Hohenhaus, A. E. (2005). 'Red blood cell transfusions in cats: 126 cases (1999)', Journal of the American Veterinary Medical Association, 226(6), pp. 920-923.

DOI: http://dx.doi.org/10.2460/javma.2005.226.920

5. McClosky, M. E., Cimino Brown, D., Weinstein, N. M., Taney, M. T., Marryott, K. \& Callan, M. B. (2018). 'Prevalence of naturally occurring non-AB blood type incompatibilities in cats and influence of crossmatch on transfusion outcomes', Journal of Veterinary Internal Medicine, 32(6), pp. 1934-1942. DOI: http://dx.doi.org/10.1111/jvim.15334

6. Sylvane, B., Prittie, J., Hohenhaus, A. E. \& Tozier, E. (2018). 'Effect of cross-match on packed cell volume after transfusion of packed red blood cells in transfusion-naïve anemic cats', Journal of Veterinary Internal Medicine, 32(3), pp. 1077-1083. DOI: http://dx.doi.org/10.1111/jvim.15120

7. Tasker, S., Barker, E.N., Day, M.J. \& Helps, C. R. (2014). 'Feline blood genotyping versus phenotyping, and detection of non-AB blood type incompatibilities in UK cats', Journal of Small Animal Practice, 55(4), pp. 185-189. DOI: http://dx.doi.org/10.1111/jsap.12180

8. Weingart, C., Giger, U. \& Kohn, B. (2004). 'Whole blood transfusions in 91 cats: A clinical evaluation', Journal of Feline Medicine and Surgery, 6(3), pp. 139-148.

DOI: http://dx.doi.org/10.1016/j.jfms.2004.01.005

9. Weinstein, N. M., Blais, M., Harris, K., Oakley, D. A., Aronson, L. R. \& Giger, U. (2007). 'A Newly Recognized Blood Group in Domestic Shorthair Cats: The Mik Red Cell Antigen', Journal of Veterinary Internal Medicine, 21(2), pp. 287-292. DOI: http://dx.doi.org/10.1111/i.1939-1676.2007.tb02962.x

10. Weltman, J. G., Fletcher, D. J. \& Rogers, C. (2014). 'Influence of cross-match on posttransfusion packed cell volume in feline packed red blood cell transfusion: Influence of cross-match on feline transfusion efficacy', Journal of Veterinary Emergency and Critical Care, 24(4), pp. 429-436.

DOI: http://dx.doi.org/10.1111/vec.12204 


\section{EVIIDEFeE

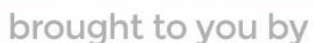 \\ RCVS KNOWLEDGE}

\section{Intellectual Property Rights}

Authors of Knowledge Summaries submitted to RCVS Knowledge for publication will retain copyright in their work, and will be required to grant RCVS Knowledge a non-exclusive license of the rights of copyright in the materials including but not limited to the right to publish, re-

publish, transmit, sell, distribute and otherwise use the materials in all languages and all media throughout the world, and to license or permit others to do so.

\section{Disclaimer}

Knowledge Summaries are a peer-reviewed article type which aims to answer a clinical question based on the best available current evidence. It does not override the responsibility

of the practitioner. Informed decisions should be made by considering such factors as individual clinical expertise and judgement along with patient's circumstances and owners' values. Knowledge Summaries are a resource to help inform and any opinions expressed within the Knowledge Summaries are the author's own and do not necessarily reflect the view of the RCVS Knowledge. Authors are responsible for the accuracy of the content. While the

Editor and Publisher believe that all content herein are in accord with current recommendations and practice at the time of publication, they accept no legal responsibility

for any errors or omissions, and make no warranty, express or implied, with respect to material contained within.

For further information please refer to our Terms of Use.

RCVS Knowledge is the independent charity associated with the Royal College of Veterinary Surgeons (RCVS). Our ambition is to become a global intermediary for evidence based veterinary knowledge by providing access to information

that is of immediate value to practicing veterinary professionals and directly contributes to evidence based clinical decision-making.

https://www.veterinaryevidence.org/

RCVS Knowledge is a registered Charity No. 230886.

Registered as a Company limited by guarantee in England and Wales No. 598443.

Registered Office: Belgravia House, 62-64 Horseferry Road, London SW1P 2AF

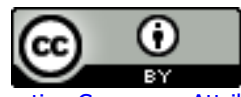

This work is licensed under a Creative Commons Attribution 4.0 International License. 